WELCOME TO CANADA: A CRITICAL EXAMINATION OF THE NEOLIBERAL RESTRUCTURING OF CANADA'S MODEL OF SETTLEMENT SERVICE DELIVERY

\author{
by \\ Zain Fattima Shah, BA, Ryerson University, 2014. \\ A Major Research Paper \\ presented to Ryerson University \\ in partial fulfillment of the requirements for the degree of \\ Master of Arts \\ in the Program of \\ Immigration and Settlement Studies
}

Toronto, Ontario, Canada, 2016

(C) Zain Fattima Shah 2016 


\section{AUTHOR'S DECLARATION FOR ELECTRONIC SUBMISSION OF A MRP}

I hereby declare that I am the sole author of this MRP. This is a true copy of the MRP, including any required final revisions.

I authorize Ryerson University to lend this MRP to other institutions or individuals for the purpose of scholarly research.

I further authorize Ryerson University to reproduce this MRP by photocopying or by other means, in total or in part, at the request of other institutions or individuals for the purpose of scholarly research.

I understand that my MRP may be made electronically available to the public.

Zain Fattima Shah 


\title{
WELCOME TO CANADA: A CRITICAL EXAMINATION OF THE NEOLIBERAL RESTRUCTURING OF CANADA'S MODEL OF SETTLEMENT SERVICE DELIVERY
}

\author{
Zain Fattima Shah \\ Master of Arts 2016 \\ Immigration and Settlement Studies \\ Ryerson University
}

\begin{abstract}
The settlement and integration of immigrants and refugees into Canadian society has become one of the most important areas of public policy in Canada. There exists a notion of a mutual responsibility between newcomers and Canadian society/state to both make the necessary adjustments to facilitate settlement and integration. Canada's main tool to fulfill its responsibility in facilitating newcomer integration is composed of the policies, programs and services that shape Canada's model of settlement service delivery. Although the Canadian model of settlement service provision is often looked to in admiration, many academics, policy makers and nongovernment workers are pointing to sings of a crisis of the settlement sector. Due to the neoliberal restructuring of the settlement sector, numerous challenges and issues have arisen for immigrant settlement agencies (ISAs) in assisting their newcomer clients. The purpose of this paper is to critically examine the crisis of the settlement sector. It is argued that the issues plaguing the settlement sector disproportionately impact smaller, ethnocentric agencies and the visible minority and racialized clients they serve.
\end{abstract}

Key Words: Canada, immigrant, newcomers, settlement, integration, neoliberal restructuring, settlement sector, non-profit. 


\section{ACKNOWLEDGEMENT}

I would like to acknowledge my amazing family, fiancé, and friends for their endless love and support. Thank you. No accomplishment would be worth celebrating without all of you by my side.

I wish to express my sincerest gratitude to John Shields for being a fantastic advisor and supervisor. Also, a special thanks to Vappu Tyyska for being an outstanding Program Director and going above and beyond in supporting her students. Thank you. 


\section{DEDICATION}

I dedicate this paper, as the capstone to my graduate studies, to my wonderful parents Raheela and Fazeelat Shah. Only through their love, hard work, perseverance and countless sacrifices have their four children been able to dream big dreams and set out to accomplish their many goals. I am forever grateful for them and all that they have done for us. Thank you. 


\section{Table of Contents}

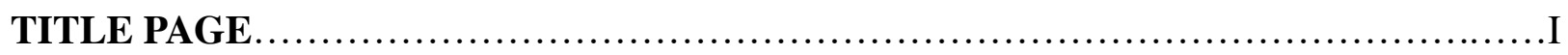

AUTHOR'S DECLARATION FOR ELECTRONIC SUBMISSION OF A MRP...........II

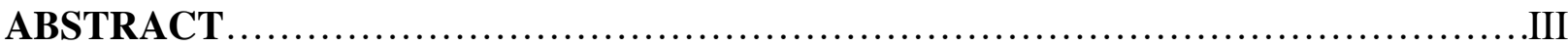

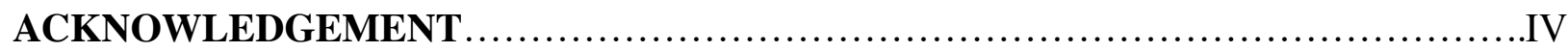

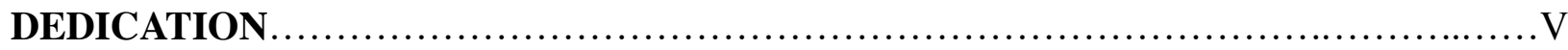

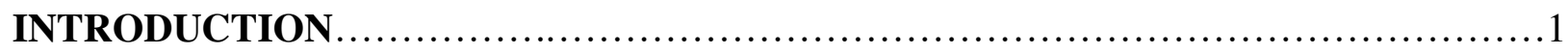

CHAPTER 1 Research Rationale and Approach................................... 5

CHAPTER 2 Understanding Newcomer Settlement and Integration ................... 8

The Early Stages of Settlement: Pre-Arrival, Adjustment and Adaptation................8

The Long-Term Stage: Integration.......................................... 9

Challenges to Settlement and Integration.....................................11

Making the Case for Visible Minority and Racialized Groups........................12

Contextualizing the Immigration and Settlement Experience of Visible Minorities......13

CHAPTER 3 Overview Canada's Approach to Newcomer Settlement and Integration.....16

Neoliberal Restructuring of the Settlement Sector................................ 17

Devolution of Settlement Service Delivery: Who does what?.......................18

Third Sector: Non-Government, Non-Profit Organizations..........................19

Federal Government.........................................................

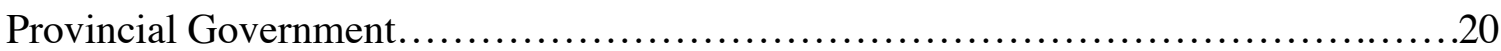

Municipal Government.....................................................20

Challenges at the Municipal Level........................................... 21

CHAPTER 4 Consequences of the Neoliberal Restructuring of the Settlement Sector.....23

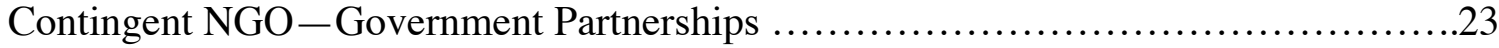

Restrictive Funding Practices................................................. 24

Forced Competition in the Sector............................................27

Excessive Administrative Accountability Requirements............................. 29

A shift in accountability to the state from public accountability $\ldots \ldots \ldots \ldots \ldots \ldots \ldots \ldots . . . . .31$

State Control Over Program and Mandate Development ............................33

Narrow service mandates focusing on short-term stages of settlement ................. 35

Impacts on Staff Morale and Service Delivery................................... 37

CHAPTER 5 Implications for Ethnocentric Settlement Agencies and Visible Minority

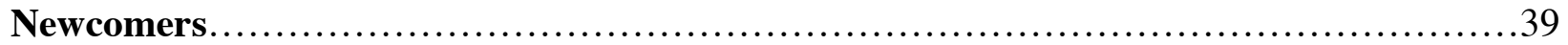

CHAPTER 6 Conclusion.....................................................44 


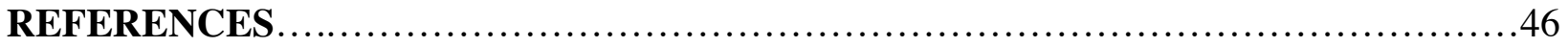




\section{Introduction}

With a drastic increase in the global movement of people in recent years and Canada's large immigrant absorptive capacity, it is no surprise that Canada has become one of the world's major immigrant-receiving countries. Having welcomed millions of immigrants and refugees since its inception, Canada is known to be the only developed country to admit roughly twothirds of the percentage of its total population annually (Young, 2011). In 2016 alone, Canada is expected to become home to up to 305, 000 new permanent residents (IRCC, 2016) - a target not met in a single year since in 1913. Compared to annual immigration targets over the past few decades, the 2016 target represents an increase of roughly 50,000¹. Clearly, Canada continues to demonstrate a strong commitment to a high intake of immigrants and refugees.

Immigration has inevitably become a fundamentally distinguishing feature of Canada's identity, having completely transformed the country's demographic landscape. Most notably, there has been a substantive diversification of Canada's foreign-born population arriving from over 200 source countries, the majority of which are now non-European. With high levels of immigration expected to continue, Canada's foreign-born population currently estimated at 20.6 percent is projected to increase to 46 percent by 2031 (Statistic Canada, 2011). Moreover, Canada boasts a large visible minority population of 19.1 percent, a figure expected to increase to roughly 32 percent by 2031 (Statistics Canada, 2011). With Canada's continual trend of high immigrant intake and its demographic landscape steadily diversifying, so too have the settlement and integration needs of newcomers become increasingly unique and complex.

${ }^{1}$ Figure represents increases in the family stream and refugee and humanitarian stream of 98.6 percent and 17.6 percent respectively, and a decrease in the economic stream of 11.4 percent (IRCC, 2016). 
Settlement supports for newcomers is not a new phenomenon in Canada. In fact, evidence of the country's first settlement services dates as far back as the late 1800s when nonprofit settlement houses originating in Britain spread to North America (Shields, Drolet, \& Valenzuela, 2016). Formal settlement services were largely established after the Second World War when the government became involved in the settlement of newcomers due to increased levels of immigration and the arrival of many European refugees with special needs. As a result of the strong political mobilization beginning in the 1960s among newcomers and those supporting them (i.e. NGOs and ethnic, religious and community-based organizations) and the introduction of an official multiculturalism policy in 1971, there was significant support for ethnocultural organizations forming the foundational framework for Canada's emerging settlement sector (Jaworsky, as cited in Tolley \& Young, 2011). Over time, a specialized settlement sector was formed in Canada (Canadian Council for Refugees, 2000).

Canada has a long history of understanding the complexities associated with immigrant settlement, as reflected by the Government of Canada's acknowledgment of the fact that newcomers face a variety of barriers to integration and its open commitment to facilitating assisting newcomers (IRCC, 2016). This commitment is reflected in Section 3(1)(e) of the Immigration and Refugee Protection Act (IRPA) which describes a mutual responsibility to ensure newcomer integration in which both the newcomers and the host society make adjustments (IRPA, 2002). Canada's efforts to fulfill its share of this responsibility is evidenced by the existence and application of settlement and integration policies, among others, that shape the country's model of settlement service provision. Newcomer settlement and integration policies - including the programs and services the policies shape - are important to examine since they provide a general reflection of the receiving society's warmth of the newcomer's 
welcome and serve as a guideline for how immigrants will be assisted on their path toward accommodation, acceptance, and integration (Evans \& Shields, 2014). The policies affect everyone, from the newcomers who are directly impacted to the host society that is indirectly impacted by the "success", or lack thereof, of immigrants and refugees. Quite simply, through the successful integration of newcomers, all Canadians enjoy a higher quality of life (IRCC, 2016).

National attitudes about Canada's settlement services are quite positive; not only are they described as "world class", but are also considered to be a major reason for the country's continual position as a "global leader" in immigrant integration (CIC News, 2013).

Internationally, Canada's model for settlement service provision has generated considerable interest and is regarded as worthy of emulation by governments and NGOs alike (Richmond \& Shields, 2005). However, only through examining Canada's settlement and integration policies, programs, and services, can important conclusions can be drawn about the "welcoming and generous" nature of Canadians towards newcomers, and relatedly the value placed in newcomers by governments and Canadian society. In recent years, immigrant settlement and integration have become one of the most important areas of public policy in Canada (Omidvar \& Richmond, 2003; Sadiq, 2004; Tolley \& Young, 2011). At the same time, with the neoliberal restructuring of the settlement sector in the mid-1990s and government neoliberal austerity agendas of the 2000s, a strong sense of urgency has emerged among NGOs and academics to research the negative impact on the Canadian settlement sector (Papillon, 2002; Richmond as cited in Sadiq, 2004). Such research has shed light on the existence of numerous issues and challenges and their serious consequences for immigrant settlement agencies (ISAs) and the clients they serve. More 
specifically, it has become evident that although the original goal of the restructuring may have been well-intended, the manner in which the goal is being executed is deeply flawed.

The purpose of this paper is to provide a critical review of the literature analyzing the crisis of the Canadian model of settlement service delivery, and the implications or ISAs and the clients they assist. To begin, the paper will provide a brief outline of the process of newcomer settlement and integration, the associated challenges, and the situation of visible minority and racialized individuals in this context. Thereafter, the paper will provide an overview of the state's approach to assisting newcomers and the settlement sector's neoliberal restructuring. A contemporary critique of neoliberal policies will then be applied to discuss the implications of the neoliberal restructuring of the sector. The main issues that will be discussed include: NGOgovernment partnerships, funding, competition, accountability requirements and service/program and mandate development. While ISAs in the settlement sector experience numerous challenges to effective settlement service provision, such as issues related to agencies' geographic location and access, due to the nature and scope of this paper, the main focus will be on issues produced largely by the neoliberal restructuring of the sector. Finally, the paper will outline the disproportionate impacts of the aforementioned issues to smaller, ethnocentric agencies, leading into a critical discussion on what the crisis of the settlement sector means for Canada's ethnocentric and visible minority populations. 


\section{Chapter 1}

\section{Research Rationale and Approach}

Qualitative in nature, the paper will be informed by the following research questions: What is newcomer settlement and integration and what is the state's role in facilitating this? What are the issues in the settlement sector stemming from its neoliberal restructuring? What are the impacts of restructuring for ISAs, including municipalities and especially smaller, ethnocentric agencies? How are Canada's visible minority and racialized individuals impacted by the sector's issues and what does this imply about their value in society? The main research for this paper will be gathered through an analysis of peer-reviewed academic articles. In addition, government and other grey literature will also be examined. Secondary data will be gathered from primary government documents, such as Citizenship and Immigration Canada (CIC) and Immigration, Refugees and Citizenship Canada (IRCC). Using Google Scholar and Ryerson University Library \& Archives, the following terms were used for the search strategy: Canadian settlement sector; Settlement and integration services in Canada; settlement and integration for newcomers and immigrants in Canada.

The focus on the settlement sector does not imply that all newcomers use or seek formal settlement services. While it is indisputable that formal settlement programs and services are very useful to a large number of newcomers, many use informal supports such as family and social circles, either in place of or in conjunction with formal supports. The purpose of making these clarifications is to accurately contextualize the settlement sector, not as the only tool available to newcomers, but Canada's only tool mandated publicly to assist newcomers in their settlement and integration process. Moreover, symbolically it is important that Canada publicly 
invests in settlement and integration as it sends an important message concerning newcomer welcome to Canada. In other words, the settlement sector is conceptualized in this paper as a representation of Canada's official policies and programs to support newcomers in the facilitation of their successful settlement and integration.

The topic of newcomer settlement and integration supports, and specifically the impacts of the neoliberal restructuring of the settlement sector, is of great significance for several reasons. Immigration has proven to be tremendously beneficial to Canada in various aspects, including supporting its economic development, increasing its global competitiveness, countering issues of low fertility rates, and an aging Canadian population and labour market. The benefits of immigration are generally well known, as evidenced by a 2011 study of 23 countries in which Canadians were second-most likely to believe that immigration has had a positive impact on their nation (Heibert, 2016). At the same time, Canada is depicted as an ideal destination for immigrants because of its reputation as an immigrant-welcoming country with new opportunities, advanced human rights, and an official policy of multiculturalism. Thus, it is fair to argue that immigration is of mutual benefit, to both the newcomers entering Canada and the existing Canadian society. This idea of a mutual benefit is expressed by the Immigration, Refugee, Citizenship Canada's Report on Plans and Priorities for 2016-2017, stating that: "generations of newcomers helped to develop Canada into the great nation we cherish today. Canadians' welcoming attitude and a strong commitment to diversity have set us apart as a people who value the contribution of every individual and community in our country. Welcoming people here in order to give them an opportunity to succeed is the very history of Canada. It's what we've always done, and it has contributed enormously to our country" (IRCC, 2016).

However, Canada is unfortunately not always the utopia many immigrants and refugees anticipate. Research points to evidence of a mismatch between the expectations and reality of Canadian life for its newcomer population (Biles \& Burnstein, as cited in Fleras, 2015; Statistics 
Canada, 2009). A growing number of immigrants and refugees are reporting dissatisfaction with their immigration and settlement experiences in Canada. The result is an increased incentive for newcomers to not remain in Canada and for prospective newcomers not to choose Canada (Biles et al., 2008). For instance, a recent internal government report by the IRCC notes that the annual rate of exit for Canadian-born citizens was $1.33 \%$ compared to $4.5 \%$ for naturalized citizens between 1996 and 2006 (Keung, 2016).

Unlike immigration experiences of the past which entailed a permanent rupture with the home society, the current immigration experience allows for immigrants to keep connected with their home country (Tolley et al., 2011) and return if their expectations in Canada are not met. As a growing number of countries are competing to attract newcomers, immigrants - especially those considered to be highly skilled - have far more alternative possible destinations to choose from (Tolley, et al., 2011). In this international immigration context, Canada must focus on differentiating itself from its competition and remain an attractive destination, thus, policies regarding attracting and retaining immigrants have become more important than ever (Tolley et al., 2011, p.1). This is especially true considering Canada seeks to select the "best and the brightest" immigrants out of its economic stream (Friederes, 2008, p.92) and has a vested interest in retaining its immigrant population. With the extensive mutual benefits to be gained from immigration, unsurprisingly, the successful facilitation of newcomers' integration and inclusion into Canadian society has become one of the most important tools for maintaining a competitive edge in attracting newcomers and leveraging the country's advantage (Tolley, et al., 2011, p.8). 


\section{Chapter 2}

\section{Understanding Newcomer Settlement and Integration}

As with any experience of beginning anew, starting a life in a new country naturally brings with it complex challenges. Each newcomer has a unique experience with settlement and integration influenced by a variety of factors, including, resources, expectations and personal experiences. A uniformed, one-size fits all approach to newcomer settlement does not exist, nor is there a fixed timeframe in which newcomers magically become settled or integrated into the host country's society. Rather, the process is often unpredictable and can be life long for some, even sometimes extending into second and third generations (Richmond \& Shields, 2005; Tolley, 2011). Newcomer settlement and integration into a new society are part of a complex, multifaceted and dynamic continuum. Generally, the process involves a four-stage process, including pre-arrival, adjustment, adaptation, and integration (discussed below). These stages of settlement and integration may overlap and there is no guarantee that the completion of one stage will naturally follow into the next.

\section{The Early Stages of Settlement: Pre-Arrival, Adjustment, and Adaptation}

The pre-arrival stage begins after a person has made the decision to migrate, when immigration documents are approved and knowledge about the new country is sought (Tolley, 2011). Upon arrival, newcomers experience the early stages of settlement: adjustment and adaptation (OCASI, 2012). In the adjustment stage, the focus is on acclimatization and becoming familiarized with the new culture, people, environment and language(s), whereas the adaptation stage involves newcomers learning and managing the new environment without requiring much 
assistance (Shields, et al., 2016). The major needs of newcomers in these early stages of settlement include: accessing Canadian systems and institutions, housing, health services, legal assistance, timely and equitable access to the labour market, access to advanced language instruction, and building a new social network (George, 2002; Mwarigha, 2002; Tam, 2003).

Beiser (2005) notes two competing arguments on newcomers' health in the early stages of settlement. On one hand, a time-specific period of understanding the mental health of newcomers is not universal, but likely to occur only among those newcomers who lack personal and social supports. On the other hand, according to community-based research, the period between 10 to 24 months after arrival to Canada is important to look at since it presents a high risk for the development of a depressive disorder. Regardless of the time-specific understanding of settlement, it is important to note that there is a need for increased supports in the early areas of settlement.

\section{The Long-Term Stage: Integration}

Although there is no single agreed-upon definition for "integration", academics, government officials, policy makers and newcomer service providers have all contributed to the varied and complex understandings of newcomer settlement and integration. Unlike the American "melting pot" goal of assimilation which requires an abandonment of one's own cultures and values, integration enables newcomers to retain their own culture while also adapting to the new society's cultures and values. The process of integration generally involves the long-term, two-way process (discussed in Chapter 3), in which newcomers become fully functioning citizens who are committed to the broader community (Shields, et al., 2016, Tolley, 2011; Tossutti, 2012). At the same time, integration is also meant to benefit Canadian society in 
their ability to fully access the human resource potential of immigrants in their community (Shields, et al., 2016). Though the understanding of "successful" integration is still largely contested (Tolley, 2011), there is a general understanding that the benchmark of success for integration is for newcomers, over a period of time, to eventually become, within a multicultural environment, practically indistinguishable from the Canadian-born population (Tolley, 2011, p. 13). Moreover, the ultimate goal of settlement and integration is for every immigrant and refugee to attain full freedom of choice and equality of participation in Canadian society (OCASI, 2000).

Generally, it is understood that that integration involves newcomers to be able to fully participate, free of barriers (Shields, et al., 2016), all areas of Canadian society including the social, cultural, political and economic dimensions:

- The social dimension involving participation in Canadian institutions and forming social contacts and group memberships. Frideres (2008) argues that the social integration of immigrants is "not an option" but a vital component of Canadian society (p.97).

- The cultural dimension referring to becoming knowledgeable about the host culture and internalizing its values and norms (Shields et al., 2016).

- The political dimension includes involvement in the political and civic activities of the host society (Shields, et al., 2016).

- Finally, the economic dimension describing newcomers finding employment with an income matching educational and experiential qualifications (Friders, 2008; Tossutti, 2012, p. 610). Arguably, the economic dimension of integration has tended to be the most focused on.

It is necessary to exercise caution in understanding the four dimensions of integration described above, specifically since it is possible to be integrated into some areas/dimensions but excluded 
in others (Phalet \& Swyngedouw as cited in Frideres, 2008). Moreover, conceptualizing these dimensions of integration as dimensions of equality, it is argued that "no one dimension is more fundamental than the others. Anything less would ultimately be liable to justify the replacement of one form of inequality with another" (Solas, 2008, p. 821).

\section{Challenges to Settlement and Integration}

To any conversation on the importance of settlement and integration services, it is crucial to consider the existence of barriers to integration and the consequences of delayed, stalled and/ or failed integration of newcomers into Canadian society. Research reveals that many newcomers often face challenges to settlement and integration. In a 2012 study of newcomers in Ontario, the top challenges expressed by respondents included securing employment (68\%), limited English language acquisition (32.7\%), social isolation (26.5\%), and finding housing (23.4\%) (OCASI, 2012). As a result of Canada's selective point-system to immigration, newcomers generally have high human capital and are accepted into the country with the assumption that they will be able to successfully integrate. Although there exists an expectation that while newcomers will struggle to some extent upon arrival, settlement supports in the new country will assist newcomers in better dealing with the transition and help them in becoming full participators in Canadian society - however, this is not always the case (Tolley, 2011).

Even with Canada's relatively lengthy and unique history and experience with the settlement of immigrants and refugees, newcomers continue to face a variety of challenges in their settlement and integration process; the consequences of these challenges remaining unaddressed for some are severe. Newcomers tend to face problems of immigrant credential and overseas work being devalued in Canada, a lack of professional networks in Canada, and racism 
and discrimination in various social setting, including the labour market (Stasiulis, Hughes, \& Amery, 2011, p. 87). It has been well established in research now that immigrants experience high levels of immigrant underemployment and unemployment (Beiser, 2005). For instance, in 2003 study of skilled workers aged 25 to 44 living in Canada for two years, 53\% reported experiences of underemployment (Stasiulis et al., 2011). Stasiulis et al. suggest that these findings related to immigrant poverty are particularly interesting considering that skilled workers were recruited by federal immigration policy because of their ability to succeed economically in Canada (2011). These issues, among others, contribute to the increased likelihood of immigrant families experiencing poverty compared to their Canadian-born counterparts (Beiser, 2005). For instance, in a 2004 study of comparing the low income rates (extending over the duration of one year) found that $42.2 \%$ newcomers reported low incomes compared to $14.2 \%$ for the general population (Stasiulis et al, 2011, p.85).

Barriers to integration, especially those that remain unaddressed, can result in an interrupted, failed or delayed integration which may lead to newcomers experiencing a lower quality of life, reduced health, poverty and general frustration (Beiser, 2005; Biles \& Burnstein, as cited in Fleras, 2015). Upon arrival to Canada, immigrants are generally in better health than their Canadian-born counterparts and the responsibility for ensuring that they remain healthy is held at the provincial level. However, deficiencies in immigration and (re)settlement policies have jeopardized this "health advantage" of immigrants (Beiser, 2005). Not only is the neglect of immigrants health and wellbeing irresponsible, it is also detrimental to their human capital and their ability to achieve their economic and social potential (Beiser, 2005). 


\section{Making the Case for Visible Minority and Racialized Groups}

All newcomers are likely to face challenges to some degree in their settlement and integration experience. The challenges faced by visible minority and racialized individuals, however, are often exacerbated by systemic challenges unique to these groups such as racism and discrimination. Immigrants, including children of immigrants, particularly visible minorities, report experiencing discrimination and exclusion, even if they meet high standards of education and qualifications (Cheung as cited in Tolley et al., 2011). Beiser (2005) notes that one in four immigrants from visible minority groups report experiences of discrimination in the early stages of settlement which can induce symptoms of depression. However, with the disproportionate impacts of the settlement sector's neoliberal restructuring faced by smaller, ethnocentric ISAs, specific services for the visible minority and racialized individuals are largely unavailable and thus their needs are often unmet. Since the role of newcomers in Canada is key to any substantial development of social inclusion, if issues in the settlement sector are left unaddressed, it would be impossible to develop settlement as a vehicle to achieve true social inclusion, in a manner that allows immigrants and refugees to actualize their full and equal participation in Canada (Omidvar \& Richmond, 2003).

\section{Contextualizing the Immigration and Settlement Experience of Visible Minorities}

It is important to note that Canada has not always been supportive of an immigration policy favouring high intakes of immigrants from visible minority groups. In fact, for decades prior to Confederation in 1867 and almost one century afterward, the explicitly racist and discriminatory immigration policies focused almost exclusively on attracting and settling white, European, mostly male immigrants in the Canadian west. Several techniques were famously 
applied by the Canadian government to attract and retain its immigrant population, including advertising and promoting Canada. Most notably, however, significant efforts exerted into easing the integration transition of Europeans into Canadian society is evidenced by the creation of societal structures, values and norms mimicking established British systems; in other words, the production of Canada's Eurocentric foundation.

It wasn't until the 1960s that Canada made several key reforms to immigration policy including the removal of explicitly racist and discriminatory country-of-origin obstacles to immigration, the introduction of a merit-based point system and later, the implementation of official policy of multiculturalism in 1971. It was only after the removal of racist immigration policies, roughly 5 decades ago, that immigrants from non-European and developing source countries began to form their place in this Eurocentric society and Canada began its journey to settle visible minority and racialized immigrants. To be sure, it is important to note that while Canada has been settling European newcomers for over for several decades before Confederation and almost one century thereafter, it does not have the same history nor experience with settling "non-Europeans". Thus, it can be argued that the settlement challenges faced by European immigrants are significantly different from those faced by non-European immigrants. More specifically, European immigrants settling in Canada would experience substantially less difficulty integrating into Canadian society due to its Eurocentric nature mirroring their country of origin and the resultant lack of systemic discrimination they may face.

Although Canada has removed explicitly racist barriers to immigration, the Eurocentric nature of Canadian systems still exists today. Moreover, even with the admittance of racialized and visible minorities into Canada through immigration policy, an abundance of evidence supports the notion that newcomers from these groups are part of a "vulnerable" population. This 
"vulnerability" does not stem from the newcomers' lack of ability to succeed, especially considering Canada's immigrant population has high human capital. Rather, it has to do with the existence of issues with systemic racism and discrimination that undermine the skills and value of these individuals and groups.

Simply put, it is important to keep in mind Canada's: a) nearly one century of explicitly racist immigration policies against visible minorities; b) 150 plus years of settling Europeans compared to less than 50 years settling "non-Europeans"; and c) the creation and existence of a Eurocentric foundation. In this vein, without undermining their capacity to integrate into new environments or victimizing them, it is argued that immigrants from non-European countries, including racialized and visible minorities, may experience more obstacles to settlement and integration. As expressed by Fleras (2015), "immigrant success depends on achieving attainment in a socially constructed system that neither reflects their lived experiences nor advances their interests" (p.11). Such an understanding of Canadian immigration and settlement history, and its present day remnants, allows for a better conceptualization of where the most need for settlement supports lies - namely, with racialized and visible minority groups. Settlement services are meant to address the varying needs of newcomers and promote their social inclusion (Murphy, 2010). Social inclusion is also "about finding out what works and mobilizing resources to resolve the problems brought about through social exclusion" (Omidvar \& Richmond, 2003, p.11). It is also understood as both a process and an end goal in which every person is able to participate and contribute as valued and respected members of society (Omidvar \& Richmond, 2003). However, as will be demonstrated later in this paper, the very agencies mandated to assist these groups have been most disproportionately negatively impacted by the neoliberal restructuring of the sector. 


\section{CHAPTER 3}

\section{Overview Canada's Approach to Newcomer Settlement and Integration}

The Government of Canada has for some time considered integration to be the ultimate goal for newcomers (IRCC, 2016; Wilkinson, 2013) and is seen as a quintessential trait of liberal democracy in Canada (Frideres, 2008, p.77). At the same time, there is a growing consensus that settlement and integration are not stand-alone issues, nor do they happen spontaneously (Tolley et al., 2011). Thus responsibility to ensure successful settlement and integration has become a "societal endeavour" (Biles, Burstein, \& Frideres, 2008, p.4) in which the government applies a "two-way street ${ }^{2} "$ approach to integration in which a two-way process that involves a mutual responsibility with the host society adjusting to newcomers as well as newcomers adjusting to their new home (Canadian Council for Refugees, 2000; Tam, 2003). Canada's main tool to fulfill its responsibility in facilitating newcomer settlement and integration into Canadian society is led by the settlement sector.

The settlement sector, understood as a specialized sector of social and human services, is a nation-wide network of immigrant settlement agencies (ISAs) with substantial experience in welcoming newcomers (CCR, 2000). The ISAs include lower level governments, institutions and the third sector: non-government organizations (NGOs), non-profit organizations (NPOs), and community-based ethnocentric agencies (see Chapter 5). ISAs work with the federal and other levels of government in a capacity in which the state providing funding for the provision of settlement and integration services to immigrants and refugees delivered at the local/community level. These services are a major and valuable part of what is involved in achieving Canada's

2 The "two-way street" model to integration was birthed through the implementation of the Immigrant Integration Strategy in 1990 (Tolley, 2011, p.27). 
goal of integrating newcomers (CCR, 2000). Moreover, it is argued that settlement services are human rights that should be mandatory for host countries to provide to newcomers (Clark as cited in George, 2002) since all immigrants and refugees arriving in Canada are entitled to such at least minimal levels of settlement support (Canadian Council for Refugees, 2000).

\section{Neoliberal Restructuring of the Settlement Sector}

"At an elementary level, neoliberalism describes a change in relationships between society and the state" (Cox, p.2, 2014). As a policy movement, neoliberalism moves from ideas of the state as a guarantor of the well-being of society, toward a system that is market-oriented replacing the state's responsibility for ensuring human welfare with individual self-reliance (Arat-Koc, 1999). Relating to immigrants, neoliberalism "reflect[s] increased expectations from immigrants and a lesser commitment from the Canadian welfare state for the rights and welfare of immigrants" (Arat-Koc, 1999, p. 32).

Neoliberalism has effectively shaped many areas of the state, including immigration and the support available to immigrants and refugees settle in Canada. Evidence of neoliberal influences on the Canadian State dates back to the 1970s and on social policies in the 1980s, yet it was not until the 1990s that significant changes stemming from neoliberal ideology became prominent in the areas of immigration and settlement policy (Arat-Koc, 1999; Richmond \& Shields, 2004). In 1993, when the Liberal government inherited an annual deficit of $\$ 42$ billion left behind from the Conservatives, the plan was to reduce the deficit to $\$ 17$ billion (Morris, 1997). With total debt reaching heights of $\$ 550$ billion in 1996 , the federal government became seriously concerned about bringing public deficits and debt under control (Morris, 1997). It was in this context that extreme neoliberal policies gained momentum and were seen as the most 
viable solution, and policies stemming from the Keynesian era and the welfare state came to be abandoned. Although decreases in settlement efforts are not unique to the 1990s, the changes happening during this period are very significant. For one, they have occurred in the context of major neoliberal policy change, making them much more difficult to challenge both politically and ideologically (Arat-Koc, 1999). Also, the policies and funding practices implemented at this time have largely been unchanged over the past two and a half decades (Mukhtar, Dean, Wilson, Ghassemi, \& Wilson,2015).

The 1990s marks a time in which the core tenants of neoliberalism - privatization, devolution of government responsibility in providing social services to non-state actors, implementation of free market principles in the non-profit sector, and marketization of social service provision (Mukhtar et al., 2015) took place at an accelerated rated. Specifically, with the implementation of the Settlement Renewal Policy of 1995 and New Public Management, the settlement sector became increasingly marketized and professionalized, thus fundamentally changing the very nature of the sector by shifting its focus from its community-based roots and creating increased pressure on society to fill the gaps opened up in social service provision.

\section{Devolution of Settlement Service Delivery: Who does what?}

The government entered into partnerships with NGOs and federally funded settlement programs began to be delivered by third-parties in the 1960s, during the period of the expansion of the classic welfare state (Young, 2011). Funding to third-party organizations for providing settlement services was formalized in the 1970s by the Department of Manpower and Immigration's creation of the Immigrant Settlement and Adaptation Program (ISAP) and the Local Initiative Program and the Employment Assistance Program (Canada, as cited in Tolley, 
2011, p. 25). Morris (1997) explains that on a continuum of state involvement in service delivery, devolution sits at one extreme and complete government control sits at the other. In the middle lie various formations of partnerships and consultations (Rodal as cited in Morris, 1997). The position of the federal government on this continuum is meant to be in this middle space in which the state maintains control of policy, monitoring and oversight while passing on service delivery, design, evaluation and adjustment to another party (ibid). However, as will be demonstrated throughout this paper, the roles of the state and non-government ISAs are not as clearly defined in the middle of such a continuum.

\section{Third Sector: Non-Government, Non-Profit Organizations}

Unlike several other immigrant-receiving countries, the majority of Canadian settlement services are funded by the government and delivered by ISAs - made up of non-profit organizations (NPOs), including community-based ethnocentric agencies - delivering supports to newcomers. Essentially, these agencies and some locally based public providers form the settlement sector. The sector is, of course, supported by government policies and program supports for settlement.

\section{Federal Government}

As per the Canadian constitution, immigration including recruitment, admission and selection of newcomers is an area of shared federal and provincial jurisdiction, with federal paramountcy. The integration process for newcomers is an area that all three orders of governments and several non-governmental organizations and community groups are involved in (Papillon, 2002). Holding the largest role in establishing integration policies in Canada, the 
federal government plays in important part in the funding and provisioning of settlement services as well (Biles, 2008, p.141). IRCC, formerly known as CIC, provides funding to ISAs for the delivery of programs and services focused on four main categories: official language acquisition through Language Instruction for Newcomers to Canada (LINC); the Host Program; Refugee Programs; and the Immigrant Settlement and Adaptation Program (ISAP), which offers the widest variety of services for core settlement programs (Biles, 2008, p. 143).

\section{Provincial government}

The federal government has entered into several formal agreements with lower level governments for greater immigration responsibilities (Papillon, 2002). For instance, through Provincial Nominee Programs, provincial governments are allowed to select a small number of immigrants to address specific labour-market needs. In terms of settlement service provision, provincial governments play a direct role in the settlement of newcomers by providing specific programs and many social services essential to the integration process (Papillon, 2002). Provinces that have agreements for settlement service provision often provide similar services as are offered under the federal programs, with some differences (Papillon, 2002). Such agreements typically include guarantees for federal funds for settlement services but do not transfer responsibility for the services to the province (Papillon, 2002).

\section{Municipal Government}

Though the federal and provincial governments have historically had the responsibility to oversee immigration and settlement issues, in recent years, municipal governments are becoming more central in influencing of settlement policy and in the provision of programs and services 
that impact successful integration (Andrew \& Hima, 2011, p. 49; Biles et al., 2008). Many services that are crucial for immigrants to support effective long-term settlement are increasingly being provided by lower levels of government (Mwarigha, 2002). With the increasing role of municipal governments, the role of the federal government is not eliminated, rather the significance of other government and non-government players increases (Tolley, 2011, p.50).

\section{Challenges at the municipal level}

According to Citizenship and Immigration Canada (CIC), the Settlement Renewal Policy would be of benefit to the settlement sector by ensuring comparable service delivery throughout Canada (as cited in Mukhtar et al., 2015). However, Arat-Koc (1999) notes that the policy has largely resulted in the disappearance of universal standards of settlement service delivery across the country. It is now well documented that provinces and cities with the highest number of newcomers experience a disproportionate burden associated with meeting settlement and integration needs (Arat-Koc, 1999; Mukhtar et al., 2015). For instance, in a study conducted by Mwarigha (2002), it was found that several major immigrant host cities in Canada, including Toronto, are very concerned about the resulting service overload issue produced by the disparity of state funding and increasing service demand.

Moreover, at the municipal level, change is taking place at a rapid rate; since the immigrant population from one place to another varies significantly, newcomer experiences and needs also vary greatly (Papillon, 2002). Major city centres have taken on the responsibility to provide more service supports to newcomers in need, but have also been obliged to deal with the various aspects of an increasingly ethno-racially diverse population with respect to municipal programs and policies (Omidvar \& Richmond, 2003). Municipalities face increased pressured 
due to the impacts of downloading excessive responsibilities by senior levels of government along with serious cutbacks to public spending and the lack of an integrated and effective nationwide policy and approach for newcomer settlement (Omidvar \& Richmond, 2003, p. 30). Unfortunately, the revenue of municipal governments, which is mostly derived from property taxes, are often insufficient and do not enable the governments to respond to the varying needs of newcomers, especially at the local level where diversity has particular significance (Papillon, 2002). Thus, municipalities are likely to request specific arrangements with provincial governments in order to fund directed activities or programs (Papillon, 2002). 


\section{CHAPTER 4}

\section{Consequences of the Neoliberal Restructuring of the Settlement Sector}

The neoliberal restructuring of the settlement sector has yielded in severely negative consequences for immigrant-settlement organizations and the newcomer clients they serve. This chapter will explore the main issues plaguing the settlement sector resulting from its neoliberal restructuring.

\section{Contingent NGO-Government Partnerships}

Accompanying the devolution of settlement service delivery responsibility, the federal government has forged complex relationships with ISAs, often referred to as "partnerships". The "NGO-government partnership" approach to settlement service provisioning is quite unique to Canada and is viewed positively by international NGOs and government's (Richmond \& Shields, 2005). As one of the defining features of Canada's settlement sector, these partnerships present an image of the Canadian government and NGOs working together on an equal playing field, being of mutual benefit and influence to one another, in catering to the need of their newcomer population. Unfortunately, this is not the case. While the state has entered into partnerships with ISAs and devolved most of its service delivery responsibilities to NGOs, it maintains ultimate central control. The devolution of the non-profit sector and the NGO-government "partnerships" have resulted in a detachment between non-profits and their clients while creating rigid and closer connections to government regulators (Mitchell as cited in Mukhtar et al., 2015). Consequently, the line between government and non-government agents is blurred as NGOs are increasingly seen as playing the role of an agent of the state in the delivery of settlement services. Effectively, these "partnerships" have created an image of the settlement sector as a sort 
of a "shadow state" or another arm of the state, which is used to legitimize power, control and pursue a neoliberal agenda that will continue to negatively impact marginalized communities (Richmond \& Shields, 2005; Shields et al., 2016).

NGO-government "partnerships" are rooted in top-down governance with clear power structures favouring the state (Papillon, 2002; Richmond \& Shields, 2004; Richmond \& Shields, 2005; Shields \& Turegun, 2013). The language of "partnerships" hides the reality of an unequal distribution of power evident in the top-down governance approach favouring the state (Evans, Richmond \& Shields, 2005; Turegun as cited in Shields \& Turegun, 2013). Non-profit service providers do not often willingly enter into these "partnerships" with government funders, rather they feel forced into them due to financial dependency and the lack of alternative resources available (Meinhard as cited in Shields \& Turegun, 2013; Turegun as cited in Shields \& Turegun, 2013). Thus, it is important to note that ISAs and the government are not involved in "true partnerships" or "true alliances" (Omidvar \& Richmond, 2003; Richmond \& Shields, 2005). Rather, they are better conceptualized as contractual agreements between non-government ISAs and the government, based on a foundation of dependency on funding and centralized control at the state level.

\section{Restrictive Funding Practices}

Since the mid-1970s, the third sector providing social services has relied heavily on the federal government for funding (Stasiulis et al., 2011). For instance, Ontario's nonprofits delivering social services received about $89 \%$ of funding from the three levels of government in the early 1990s (Eakins as cited in Richmond \& Shields, 2004). In recent years, ISAs’ dependency on the state for funding has only increased since there is a higher demand for 
settlement supports among newcomers (Mwarigha, 2002; Omidvar \& Richmond, 2003;

Richmond \& Shields, 2004; Richmond \& Shields, 2005). The increase in demand results from a combination of backlogs resulting from decades of funding freezes and cuts and the rapid diversification of the newcomer population. Though it is generally understood that as demand goes up, supply -- and associated funding - should also increase, this has generally not been the case in the settlement sector. In fact, the reality of the sector post-neoliberal restructuring is increased demand for services without an increase in funding and resources and the new norm is to do more with less (Richmond \& Shields, 2004).

Funding practices within the social service sector have created an environment in which the lowest expenses are the desired outcome (Sadiq, 2004), thus resulting in ISAs struggling to run their services without experiencing organizational financial losses and deficits while also addressing the increasing demands of newcomers. As a result, many immigrant-serving agencies are now in a precarious state as they struggle with service overload, the absence of financial means, organizational income instability and vulnerability (Evans, Richmond \& Shields, 2005; Mukhtar et al., 2015; Omidvar \& Richmond, 2003; Richmond \& Shields, 2004). Under such precarious working conditions, several aspects of successful settlement service provision have become extremely difficult, if not impossible, for many ISAs. In a 2005 study conducted by Simich, Beiser, Stewart, and Mwakarimba, the greatest challenge to settlement service provision described by participants was a loss of resources.

Though the government has transferred a significant amount of responsibility to NGOs for settlement service delivery, it has failed to transfer adequate funding for service provision. Rather, with the restructuring of the sector, funding cuts simultaneously taking place for immigrant services throughout the provinces (Mukhtar, et al., 2015). For instance, in the mid 
1990s funding cuts to settlement services were roughly 20 percent for larger agencies and 40 percent for smaller agencies (Mwarigha as cited in Sadiq, 2004). In Ontario, as NGOs took on increasing responsibility for settlement service provision in the 1990s, settlement programs experienced funding cuts of almost 50 percent and many programs were either overturned or completely eliminated (Richmond \& Shields, 2004). Cuts in funding are not unique to the period of the 1990s. In fact, although there were instances of funding increases, in 2011, the Conservative Government cut settlement funding by $\$ 53$ million, with more than $80 \%$ of the cuts experienced in Ontario (OCASI, 2011).

Moreover, when funds are provided to ISAs for settlement service delivery, the number of funding dollars is often insufficient since the state generally provides funds for program delivery but fails to fund the necessary administrative components of the work (Evans, Richmond \& Shields, 2005). As noted by Eakin, there is a significant underfunding of services as government funding often does not cover the entire cost associated with settlement programs, generally falling 7\%-15\% short of actual costs (as cited in Richmond \& Shields, 2004).

In addition to the deliberate underfunding, the quality of funding has also suffered as the sector is facing a devastating shift from "core" or "base" funding to unstable "contract" or “program” funding (Mukhtar et al., 2015; Richmond \& Shields, 2004; Richmond \& Shields, 2005; Shields \& Turegun, 2013). Contract funding is also described as a tool that is used by the state to exert control over service providers to enable the state to specify outputs, closely control spending, and leave minimal flexibility for program delivery (Eakin as cited in Richmond \& Shields, 2004, p. 8; Evans, Richmond \& Shields, 2005; Richmond \& Shields, 2004). With contract funding, there is a focus on allocating dollars to short-term and often one-off projects, in which funds do not last more than the duration of one year. This has come at the expense of more 
valuable long-term funding for multi-year projects. Additionally, the short-term nature of funding requires agencies to constantly exert time, energy and resources in preparing grant proposals in order to apply for the next funding contract - an extremely time-consuming task that takes away valuable resources from other areas of settlement work.

Due to the lack of continuity in programs associated with contract-funding, program evaluation has become extremely challenging (Biles, 2008). Program evaluation processes are vital as they allow service providers to participate in critical reflection, identify areas for improvement and encourages problem-solving strategies. Moreover, long-term planning for programs and services and the assessment of long-term outcomes have become difficult, if not impossible for some ISAs, thus reducing the ability of ISAs to develop quality programs to proactively address the evolving needs of newcomers (Evans, Richmond \& Shields, 2005; Mukhtar et al., 2015; Shields \& Turegun, 2013).

\section{Forced Competition in the Sector}

Through the influence neoliberal ideologies and the focus on the marketization of the sector, the state has used limited funding as a mechanism to ensure proper competition among ISAs (Flynn \& Bauder, 2014; Mukhtar et al., 2015). Simply put, funding for settlement services is not merely provided to ISAs - it is won by ISAs compelled to partake in competition against one another to win funding from a limited pool of available funds. In recent years, with the funding requirements becoming more stringent and cuts in funding having grown, the competition in the sector has greatly intensified (Evans \& Shields, 2014). In a 2015 study conducted by Mukhtar et al., competition between ISAs was the third most reported challenge (2015). Unsurprisingly, the sector's competitive atmosphere has resulted in numerous negative 
consequences for ISAs, contributing to the increasing instability of the sector (Evans, Richmond \& Shields, 2005).

Competition among ISAs meant to push the sector toward a "business model", reduce the cost of programs, eliminate from the competition ISAs who are unable to meet the vigorous demands of the government priorities and provide greater choices for newcomers (Evans, Richmond \& Shields, 2005; Milligan as cited in Sadiq, 2004; Owen as cited in Sadiq, 2004). Although the implementation of competition between ISAs has achieved the goal of restructuring the settlement sector along quasi-market lines and achieving more of a business model, this has happened at the expense of ISAs losing a large part of their community-centred focus (Evans \& Shields, 2014). Like many other problematic features of the sector, competition among ISAs is not a mistake - it is deliberately built into the system as a way to follow market rules and as a tool to promote more "efficiencies" in providing publicly supported services (Richmond \& Shields, 2005, p. 517; Shields et al., 2016). However, some of the consequences of such an atmosphere were not anticipated and work against other objectives the state sets for ISAs. A serious consequence of promoting competition between ISAs is that the settlement sector now fosters an extremely politicized environment. This has resulted in an erosion of trust between ISAs and a steady deterioration in their cooperation and collaborative working relationships with fewer genuine partnerships being formed (Evans \& Shields, 2014; Mukhtar et al., 2015; OCASI, 2013; Sadiq, 2004; Shields \& Turegun, 2013). Interestingly, the deteriorating relationship between ISAs is both an unintended and ironic consequence of the competitive nature of the sector. The government encourages collaboration between ISAs and expects communication and coordination with one another to, for example, minimize the risk of service duplication in a particular catchment area (Duvieusart-Déry et al. 2013 as cited in Mukhtar et al., 
2015). However, due to the intensified competition not only to get funding but also meet

mandatory quotas, many ISAs operate in a vacuum, focusing mainly on serving as many newcomers as possible in order to meet their quota (Mukhtar et al., 2015). Thus, ISAs have reported a general decline in lack of referrals to their own agencies from other ISAs (Mukhtar et al., 2015). These issues are more pronounced between larger, multi-service ISAs and smaller ethno-specific ISAs since larger agencies are viewed with distrust and resentment by their smaller counterparts when they are in the same catchment area (Mukhtar et al., 2015). Moreover, the politicized environment has resulted in a significant reduction in knowledge sharing and capacity building efforts among ISAs, thus, negatively impacting the quality of programs and services for newcomers.

\section{Excessive Administrative Accountability Requirements}

With the common trend under neoliberal governance systems of transferring risk and accountability downward (Taylor as cited in Evans, Richmond \& Shields, 2005), funding contracts provided by the state to ISAs are strictly governed by rigid administrative accountability requirements. The Panel on Accountability and Governance in the Voluntary Sector (as cited in Evans, Richmond \& Shields, 2005, p. 83) defines accountability as the duty to explain the details of how a responsibility for an appointed task has been executed with the purpose of ensuring that goals are met - a duty that is especially crucial in situations involving public trust. More specifically, the state has expanded accountability requirements and evaluation standards attached with funding contracts in order to ensure that "funds are spent in accordance with the conditions laid out in the funding contract" (Evans, Richmond \& Shields, 2005, p. 14). ISAs are increasingly burdened by the state-imposed necessity of demonstrating accountability 
to the funder through means of excessive administrative practices of data collection and reporting. In recent decades, the significance of accountability requirements has grown rapidly as a way to maximize the impact of settlement and integration funding expenditures and hold NPOS - which hold a trusted place in society and have clear ethical responsibilities - answerable for problems (Jeavons as cited in Richmond \& Shields, 2005).

The administrative burdens associated with managing funder expectations with accountability requirements are very expensive to maintain for ISAs, sometimes costing as much as 20 percent of the value of the funding contract (Phillips as noted in Richmond \& Shields, 2005). These burdens have resulted in an overall transition of precious resources - both human and financial - to responding to the reporting demands of the funders. In an environment where funding and resources are already increasingly limited and inadequate, accountability requirements imposed on ISAs further deplete their limited resources. Under the guise of improving the settlement sector, the excessive administrative burden attached with accountability requirements have resulted in numerous negative consequences for ISAs.

In an environment already characterized by low financial and human resources, high levels of valuable time, energy and resources are spent in "administrative wrangling" (Papillon, 2002, p.21) needed to satisfy the government's arbitrary accountability requirements. The burden of excessive administrative accountability requirements are draining the already limited time and resources of ISAs, inhibiting them from working on areas of more significance, such as policy development, program planning and enhancement, community outreach and education, and learning more innovative approaches (Evans \& Shields, 2014; Omidvar \& Richmond, 2003; Papillon, 2002; Richmond \& Shields, 2004; Meinhard as cited in Shields \& Turegun, 2013). Consequently, excessive accountability requirements are producing more compliant agencies at 
the expense of high administrative costs and fewer efforts dedicated to settlement program enhancement and most importantly, newcomers (Evans \& Shields, 2014).

\section{A shift in accountability to the state from public accountability}

State-imposed administrative accountability on ISAs largely disregards public interest. Richmond and Shields (2004, p. 4) argue that "there is a fundamental paradox inherent in the fact that such restructuring is being imposed without public debate in the name of the public good". Techniques of accountability are simply "evaluation" schemes used as managerial mechanisms to exert strict and narrow governmental control over ISAs (Charon \& Richmond as cited in Omidvar \& Richmond, 2003; Evans, Richmond \& Shields, 2005; Morris as cited in Mukhtar et al., 2015 p. 3; Richmond \& Shields, 2005). This has resulted in a form of control understood as centralized decentralization in which the state controls outcomes by means of market-based contractual agreements which are accompanied by managerialist accountability requirements (Richmond \& Shields, 2005). Specifically, the state is interested in increasing control over the management of how funding is spent and programs are delivered (Richmond \& Shields, 2005).

The narrow form of administrative accountability has replaced the more informal trust relationships that existed prior to the restructuring of the sector (Evans, Richmond \& Shields, 2005). This demonstrates the government's general lack of trust of ISAs and their justification of excessive control mechanisms. Evidently, the neoliberal contractual agreements between NGOs and the government and the attached accountability schemes have increasingly strained the relationship between the two parties (Mukhtar et al., 2015; Richmond \& Shields, 2005).

The state-imposed complex and burdensome accountability requirements are schemes to exert more state control operating under the guise of evaluation measures, contributing to a 
misconception by state funders that administrative accountability is the same as public accountability (Richmond \& Shields, 2004, p. 3 \& 18). The reality of the matter, however, is that the "one-dimensional focus" on administrative accountability to the state and other funders has overshadowed, or replaced, public accountability (Richmond \& Shields, 2004; Richmond \& Shields, 2005; Evans, Richmond \& Shields, 2005). In order to demonstrate that sufficient efforts (i.e., financial support, infrastructure, and long-term goals) are in effect to sustain desired public supported social services, public accountability involves the government's responsibility to provide a full account, in public manner, for the types of support being dedicated to the supply of such public goods and services (Richmond \& Shields, 2005). The replacing of the government's public accountability with ISAs accountability to the state has enabled the government to avoid blame or responsibility for the underfunding or the deteriorating quality of public services; instead, blame has been shifted onto non-profit ISAs (Richmond \& Shields, 2005).

Evans, Richmond, and Shields suggest that accountability to government funders holds precedence over other accountability obligations (2005). The situation with accountability in the sector is such that the state is no longer accountable to the public and ISAs are accountable to the state at the expense of the community they are mandated to serve. With the burden of administrative reporting associated with accountability to the state having grown rapidly in recent years, service providers are facing a host of challenges in accommodating the state's demands while meeting their clients' needs. The extent to which accountability requirements attached with funding contracts have become stringent has resulted in grants increasingly being viewed as "unworkable" by local organizations (Mukhtar et al., 2015). 


\section{State Control Over Program and Mandate Development}

Another major consequence of the neoliberal restructuring is that Canadian settlement services have suffered severely, particularly in their quality (Sadiq, 2004, p. 13). The sector's restructuring has tended to work against basic goals of service providers, such as strengthening community voices and genuine consultations with the government (Richmond \& Shields, 2004). As aforementioned, lowest expenses are the desired outcome in a sector influenced by neoliberal principles. Consequently, ISAs "either abandon best practices in favour of lowest cost practices or continue to engage in best practices and operate at a deficit. In other words, they must choose between reducing the quality of service or ceasing operations" (Sadiq, 2004, p. 17).

Due to the unequal distribution of power associated with the devolution of settlement service delivery, ISAs are substantially constrained in their independence, autonomy, and decision-making role pertaining to program design and mandate development. Prior to the restructuring of the settlement sector, ISAs self-designed their settlement programs and selfdetermined their mandates (Salamon \& Miller as cited in Mukhtar et al., 2015, p. 3). Now, the terms and conditions for settlement programs are dictated by the funder with minimal input from service providers (Evans, Richmond \& Shields, 2005; Papillon, 2002; Sadiq, 2004; Richmond \& Shields, 2004; Richmond \& Shields, 2005; Shields \& Turegun, 2013). Specifically, the government's priorities are imposed upon ISAs dependent on state dollars through contingent funding contracts and most settlement programs and services are now developed vertically at the government level (Papillon, 2002; Sadiq, 2004). As a result, ISAs may be viewed as merely as “the 'distributors' of settlement services that serve the need of the 'supplier' of settlement funding (government) rather than the 'consumers' of their services (newcomers)" (Mukhtar et al., 
2015 , p. 4). The role of the ISAs is reduced simply to the delivery rather than the development of settlement services.

It has become increasingly evident that the neoliberal restructuring of the sector has been used as mechanisms to exert deeper state control over ISAs and the cost and structure of settlement services and programs (Handy as cited in Evans, Richmond \& Shields, 2005, p. 80). Fearful of losing the competition for state funding, or not having funding renewed, ISAs target their grant proposals and program pitch more and more in line with what the state is willing to fund instead of what the ISAs believe to be newcomers demands (Richmond \& Shields, 2005). Through such fear-induced behaviour, the state exercises its power and control over ISAs in defining their own mandate.

The role of ISAs in the research, planning, and development of settlement programs is extremely limited due to government control in this area. Community involvement in the development of nonprofit services has also declined significantly. Since knowledge about newcomer needs is mainly at the community level (Papillon, 2002), the lack of community involvement in the development of settlement programming is very problematic. ISAs are extremely limited in developing programming outside of their contractual terms of agreement with the government (Evans, Richmond \& Shields, 2005; Sadiq, 2004). Because only those programs that are approved for funding can be offered to newcomers, the supply of newcomer services in Canada is directly impacted by settlement funding (Sadiq, 2004). Mukhtar et al. (2015) argue that the implementation of competitive contract funding should result in settlement service supply meeting newcomer demands. However, the government often fails to match funds with client needs. For instance, although there is an increasing newcomer population in the outer suburbs, there is still an underrepresentation of ISAs in these areas (Truelove, 2000 \& Lo et al., 
2007 as cited in Mukhtar et al., 2015). Unfortunately, the role of deciding what is and is not "deserving" of funding is largely held by the federal government. Essentially, programs for immigrants and refugees are developed according to what the government assumes the need to be, rather than what agencies and the community know the need to be.

\section{Narrow service mandates focusing on short-term stages of settlement}

ISAs must focus on providing programs and services mandated by the state: those focusing on immediate, rather than long-term, settlement needs of newcomers. Though newcomer settlement is generally regarded as a three-stage process - adjustment, adaptation, and integration - the government mainly focuses on funding the first rather than the latter two stages (Tam, 2003). While integration is "the optimal goal" for any immigrant-receiving country (Wilkinson, 2013), the Canadian government enforces mandates on ISAs which focus only on the short-term settlement rather than the long-term integration needs of newcomers. As Mwarigha (2002) notes, settlement services do not cover some of the vital long-term dimensions of the settlement process, such as community development initiatives, access programs for housing, health and other social services or market-oriented skills development programs. For instance, settlement services generally address the principal needs of newcomers, including employment, housing, official language acquisition and basic orientation (Tam, 2003). Yet, the narrow service mandates cripple the ability of immigrant-serving agencies to provide more longterm, meaningful programs thus preventing them from assisting newcomers in a holistic way (Simich et al., 2005).

The focus for settlement has become economic integration and short-term measurable results, rather than the more holistic and long-term settlement process that settlement agencies 
understand and strive to support immigrants and refugees with (Meinhard as cited in Shields \& Turegun, 2013). Yet, newcomers most value supports in the areas outside the current mandates of federal immigration and settlement policy. The federal government's settlement programs provide basic welcome services and deal mostly with the early stages of the settlement process (Mwarigha, 2002; Papillon, 2002). Yet the mandate of settlement goes beyond such limited welcome services (Mwarigha, 2002). To compound this issue, for years, service providers have argued that the federal CIC-funded settlement programs are seriously limited since among refugee claimants, immigrants residing in Canada more than three years, and those have acquired Canadian citizenship are all considered to be ineligible for programming (Mwarigha, 2002).

Moreover, the government discourages agencies from partaking in certain activities on taxpayer dollars, such as independent advocacy, service providers have drastically reduced their participation in such activities in an attempt to survive in the competitive environment. Through catering to government requirements, the settlement sector has experienced a growing loss of diversity in programs and services (Omidvar \& Richmond, 2003; Evans, Richmond \& Shields, 2005). Many settlement programs and services have been transformed, limited or even eliminated with the implementation of neoliberal policies. While some areas of settlement service provision have experienced cuts in funding as a result of the restructuring, others have faced a complete elimination of funding. For example, while funds have been cut for groups advocating on behalf of newcomers, funding has largely been eliminated for programs that promote employment equity and anti-racism - areas that are vital for long-term integration of newcomers (Sadiq, 2004).

Omidvar and Richmond (2003, p.8) argue that the lack of a Canada-wide and long-term view that takes all stages of settlement into account is one of the most pressing problems of the 
settlement sector. As a consequence of the restrictive state-imposed service mandates, ISAs have become severely limited in their ability to develop holistic and sustainable social supports that allow newcomers to overcome the barriers to integration (Simich et al., 2005) and feel supported throughout the lifetime of their integration processes and experiences. Papillon (2002) argues that the state's focus on short-term settlement needs may contribute to a difference in the integration of certain groups facing greater barriers, mostly visible minorities and immigrants with limited social and human capital - the very groups who rely most on settlement services and require longer-term care (Papillon, 2002). For instance, if settlement service providers understand the specific needs of a particular community that the government is not willing to fund, those community needs are left unaddressed.

\section{Impacts on Staff Morale and Service Delivery}

As a consequence of limited financial and human resources for ISAs to deal with the burdensome requirements of the state funders while meeting the growing needs of newcomers, service delivery and staff morale has been negatively impacted (Sadiq, 2004). Due to the general lack of funding for settlement services, many ISAs cannot afford to pay higher wages to staff, cannot hire additional staff, and heavily rely on volunteer staff as well (Sadiq, 2004). As such, most ISAs are composed of individuals (workforce) who are underpaid and overworked professionals and unpaid non-professionals - this combination of staff is not fit to meet the increasingly complex and unique needs of Canada's newcomer population, especially in an environment of increased demand for settlement services. It is not surprising then, as Sadiq (2004) observes, limited financial and human resources have affected staff morale in many ways, including physical fatigue; fears of ending short-term project funding; reduced service delivery 
time due to increasing participation in fundraising (Sadiq, 2004). Such negative impacts on staff morale have direct implications for service delivery and interactions with newcomer clients.

Specifically, the consequence is that staff may be unable to provide quality services to the individuals and communities they are mandated to assist (Sadiq, 2004). 


\section{CHAPTER 5}

\section{Implications for Ethnocentric Settlement Agencies and Visible Minority Newcomers}

It is well established in the literature that the neoliberal restructuring of the settlement sector has produced various challenges for ISAs, specifically pertaining to settlement service provision. "All the surviving agencies, big or small, multi-ethnic or ethno-specific, multi-service or specialized, struggle collectively with the burdens of service overload, and lack of funding" (Mwarigha, 2002, p. 21). However, there is also a general consensus that wellestablished ISAs, generally, the larger multi-service agencies, can significantly mitigate the challenges and negative consequences (Mukhtar et al. 2015). Generally, the ISAs that have suffered the most as a result of the restructuring are smaller, less-established agencies, in particular, those that operate with ethno-specific focus (Mwarigha, 2002; Omidvar \& Richmond, 2003). In this section, I will outline the ways in which the issues resulting from the neoliberal influences on the sector disproportionately impact these ethno-specific agencies.

Though several ISAs are now in a precarious state due to the state-imposed restrictive funding practices, smaller agencies tend to be at higher risk than their larger counterparts which have more administrative resources to manage contractual programs and their attached administrative accountability requirements (Omidvar \& Richmond, 2003). Smaller ethnocentric ISAs have been most severely impacted due to the general lack of resources available to smaller agencies to dedicate to burdensome administrative duties. For instance, the emphasis on accountability is mostly concerned with the monitoring of budgets financial reporting requirements, an area that larger agencies, more than smaller ISAs, are better equipped to deal with due to sophisticated bookkeeping procedures (Sadiq, 2004). 
Evidently, larger agencies that have more administrative resources to manage contractual programs are favoured in a system where the government funding patterns have transitioned from “core" to program-specific funding (Omidvar \& Richmond, 2003). Mwarigha (2002), suggests that funders are largely interested in the organizational capacity of ISAs to provide services, as opposed to their creativity or ability to address community needs. Thus, a devastating consequence in the settlement sector is the erosion of the supply of ethnocentric ISAs and the marginalization of the ethno-racial settlement sector (Mwarigha, 2002; Sadiq, 2004). This is especially problematic in a city like Toronto with high immigration and diversity, and immigrants in need of services catering to over 100 languages (Mwarigha, 2002) - a need best met by smaller, ethno-specific agencies. Even though smaller ethnocentric ISAs are better able to offer services to emerging communities than larger multi-service agencies, the lack of funding provided to these agencies demonstrates the unfortunate reality of the restructured settlement sector: funders are mainly interested in the organizational capacity of ISAs to deliver services, rather than their ability to actually address community needs (Mwarigha 2002).

The deliberate competitive environment of the sector has resulted in a growing monopolization by larger, multi-service ISAs at the expense of smaller, ethnocentric, community-based ISAs (Mukhtar et al., 2015; Mwarigha, 2002; Richmond \& Shields, 2005; Sadiq, 2004). Generally, larger multi-service organizations have been the survivors of the competition largely due to funder preference to work with agencies that have greater administrative resources to dedicate to the challenges of restructuring (Richmond \& Shields, 2005, p. 17; Sadiq, 2004). On the other hand, because of their lack of both human and monetary resources to make up for limited funding, smaller, ethnocentric ISAs often experience difficulty in fulfilling burdensome administrative and grant writing requirements and also face the danger 
of operating at a deficit (Mukhtar et al., 2015). Thus, these ISAs are in an unequal position to compete with their larger counterparts. Consequently, many smaller, community-based ISAs, especially ethno-specific and ethno-racial agencies, have become marginalized (Mwarigha, 2002) and are often forced into either limiting their services, partnering with larger, multi-service agencies or even completely shutting down (Richmond \& Shields, 2005). Those that are still running operate under conditions of extreme stress (Omidvar \& Richmond, 2003). Simply put, smaller agencies are often completely eliminated from the market and new competition is unable to rise, resulting in significantly reduced competition for surviving ISAs - generally, the larger, multi-service agencies (Mukhtar et al., 2015).

Furthermore, Mwarigha (2002) notes that since many smaller agencies have not survived the competitions, there is an overall reduction in the number of service providers and services. Sadiq (2004) suggests that the introduction of a market-based competitive funding approach should produce more choices for newcomers in ISAs, programs and services. However, this is not the case since the sector's competitive structure has resulted in an eroding of the supply of service providers (Mukhtar et al., 2015). Since this reduction in ISAs has come at a time when the need for settlement services is high, surviving ISAs are scrambling to meet the increased demands of newcomers (Mwarigha, 2002).

Ethnocentric ISAs are also most impacted by the government's control over the mandate development as a result of their increased dependency on state funding. As a result, during the process of crafting a mandate, they risk losing their sense of autonomy and their ability to participate in the development of policies that best serve the needs of specific communities is severely compromised (Sadiq, 2004). Richmond and Shields (2005, p. 517) argue that ISAs have historically played a vital role in settlement policy development as well as advocating for anti- 
racism and equity and promoting newcomer community development. However, the restructuring of the sector presents an ongoing threat to eliminate these vital roles for ISAs to contribute to newcomer advocacy and promotion. O’Sullivan (as cited in Richmond \& Shields, 2005) observes that ISAs are adjusting and surviving in the settlement sector at the expense of a significant reduction in programs and services for the most "vulnerable" newcomers, a loss of independence, "mission drift, and reduced advocacy" (p. 518).

Arat-Koc argues that a result of the state's neoliberal restructuring of settlement policies, biases against "deserving" and "undeserving" immigrants — which have long existed in immigration and settlement policy - have become more overt and evident (1999). For instance, she explains that neoliberalism emphasizes global competitiveness and prefers immigrants who are highly educated, skilled, independent and wealthy, who will be able to contribute to the Canadian economy immediately upon arrival, with little to no state support. In the same vein, while the changes have exaggerated the already existing hierarchy in classes of immigrants (Arat-Koc, 1999), they have also produced another hierarchy in the agencies mandated to service newcomers. Thus, the notion of "deserving" and "undeserving" discussed by Arat-Koc has extended to ISAs including the various programs and services they offer, and the clients they serve. 


\section{CHAPTER 6}

\section{Conclusion}

There is no doubt that vast improvements have taken place in Canadian immigration and settlement policies - evidencedy by the drastic shift from a history of explicit racism and discrimination to present day values of diversity and multiculturalism. Canada's advanced immigration policies and established settlement sector are often viewed as evidence of such strides made in Canadian policies. However, while national and international praise of the Canadian model does exist, the unfortunate reality is that the Canadian approach should no longer be looked at as a case of best practice or with a desire for emulation. Rather, as this paper has demonstrated, the settlement sector was created with a purpose to assist in the successful settlement and integration of newcomers, a goal that has been significantly disrupted by the implementation of neoliberal ideologies and policies in social policies.

As a growing body of literature points out, the reality of the neoliberal restructuring of the sector is not only that it is limiting ISAs in their ability to assist newcomers, but also ultimately leaving newcomers increasingly responsible for facilitating large portions of their integration alone (Wilkinson, 2013). It has become evident that the system of settlement service provision in Canada is unfortunately not working (Richmond \& Shields, 2005). This reality not only taints Canada's image as an immigrant-friendly nation, but can also represent a loss of potential benefits to be reaped by both newcomers and the host society. For instance, the economic and social benefits can only be attained if newcomers not only choose to remain in Canada but also secure housing, employment, and have a promising future (Tolley et al., 2011, 
p. 2). Simply put, if newcomers are unable to successfully integrate, immigration will not be able to fulfill the goals that Canadian society has established (Tolley et al., 2011).

It would be naive to assume that the restructuring of the sector, including severe fiscal restraints, is the result of an anti-immigration environment in Canada since Canada is a selfprofessed nation of immigrants and continues to be pro-immigration (Arat-Koc, 1999; Biles, 2008; IRCC, 2016). It would also be simplistic to assume that it is merely the result of budgeting concerns. Rather, it is more useful to understand the changes as the result of the state's differential "categories" of immigrants and its shaping of public expectations (Brodie as cited in Arat-Koc, 1999). Arat-Koc explains neoliberal influences as helping to shape our ideas on what Canadians - newcomers and citizens - can reasonably expect from the state (1999). She further argues that according to neoliberalism ideologies, welfare state principles are no longer valid, including the idea that Canadians can enjoy the rights to basic standards of life and the state is responsible for their individual welfare. Instead, there is an exaggerated emphasis on selfreliance and independence. However, Canada's longstanding and ongoing dependency on immigrants suggests that a different approach to newcomer settlement and integration be taken into consideration. 


\section{References}

Andres, C. \& Hima, R. A. (2011). Federal Policies on Immigrant Settlement. In Tolley, E., \& Young, R. (Eds.) Immigrant Settlement Policies in Canadian Municipalities, (pp. 49-73). McGill-Queen's University Press.

Arat-Koc, S. (1999). Neoliberalism, State Restructuring and Immigration: Changes in Canadian Policies in the 1990s. Journal of Canadian Studies 34(2), 31-56.

Beiser, M. (2005). The health of immigrants and refugees in Canada. Canadian Journal of Public Health / Revue Canadienne De Sante'e Publique, 96, 30-S44.

Biles, J. (2008). Integration Policies in English-Speaking Canada. In J. Biles, M. Burstein, \& J. Frideres (Eds.), Immigration and Integration in Canada in the Twenty-first Century (pp. 139-187). Kingston: School of Policy Studies, Queen's University.

Biles, J., Burstein, M. L., \& Frideres, J. (2008). Introduction. In J. Biles, M. Burstein, \& J. Frideres (Eds.), Immigration and Integration in Canada in the Twenty-first Century (pp. 1-19). Kingston: School of Policy Studies, Queen's University.

Frideres, J. (2008). Creating an Inclusive Society: Promoting Social Integration in Canada. In J. Biles, M. Burstein, \& J. Frideres (Eds.), Immigration and Integration in Canada in the Twenty-first Century (pp. 7-103). Kingston: School of Policy Studies, Queen's University.

Biles, J., Tolley, E., Andrew, C., Esses, V., \& Burstein, M. (2011). Integration and Inclusion in Ontario: The sleeping giant stirs. In Biles, J., Burstein, M., Frideres, J., Tolley, E., \& Vineberg, R. (Eds.) Integration and Inclusion of Newcomers and Minorities across Canada (195-246). Montreal \& Kingston: McGill-Queen's University Press.

Canadian Council for Refugees (1998) Best Settlement Practices: Settlement Services for Refugees and Immigrants to Canada. Ottawa: Canadian Council for Refugees.

CIC News (2013). Canada's World-Class Settlement Services. Retrieved from: http:/ www.cicnews.com/2013/04/Canadas-worldclass-settlement-services-042406.html

Citizenship and Immigration Canada (CIC). (2013). Facts and Figures 2012 - Immigration overview: Permanent and temporary residents. Retrieved from http://www.cic.gc.ca EnGLish/resources/statistics/facts2012/temporary/1 3.asp

Cox, C. R. (2014). International students in Canada: Policies and practices for social inclusion (Unpublished masters major research paper). Ryerson University.

Evans, B.M. \& Shields, J. (2000). Neo-liberal restructuring and the Third Sector: Reshaping Governance, Civil Society, and Local Relations. Toronto: Centre for Voluntary Sector Studies, Ryerson University, Working Paper \#13. 
Evans, B., Richmond, T., \& Shields, J. (2005). Structuring neoliberal governance: The nonprofit sector, emerging new modes of control and the marketisation of service delivery. Policy and Society, 24(1), 73-97.

Fleras, A. (2015). Immigration Canada: Evolving realities and emerging challenges in a postnational world UBC Press.

Flynn, E., Bauder, H., \& Ryerson Centre for Immigration and Settlement. (2013). The private sector, institutions of higher education, and immigrant settlement in Canada Ryerson Centre for Immigration and Settlement.

Frideres, J. S., Burstein, M., Biles, J., \& Queen's University (Kingston, Ont.). School of Policy Studies. (2008). Immigration and integration in Canada in the Twenty-First Century School of Policy Studies, Queen's University.

Frideres, J. (2008). Creating anInclusive Society: Promoting Social Integration in Canada. In Immigration and Integration in Canada in the Twenty-First Century. (p. 77-103).

George, U. (2002). A needs-based model for settlement service delivery for newcomers to Canada. International Social Work, 45(4), 465-480.

Hiebert, D. (2016). Whats So Special About Canada? Understanding the resilience of immigration and multiculturalism. (pp. 1-18)

Immigration, Refugee and CitizenshipCanada (CIC), (2016), Reports on Plans and Priorities 2016-2017. Retrieved from: http://www.cic.gc.ca/english/resources/publications/rpp 2016-2017/

Keung, N. (2016). Gloomier future seen for Canadian immigration; 'national conversation' urged in view of challenges identified in internal review. The Toronto Star (Toronto, Ontario).

McGrath, S., \& McGrath, I. (2013). Funding matters: The maze of settlement funding in Canada and the impact on refugee services. Canadian Journal of Urban Research, 22(1), 1.

Morris, J. (1997). Neo-liberal strategies to cut costs in settlement services: cost recovery and devolution. Refuge: Canada's Journal on Refugees, 15(6). Chicago

Mukhtar, M., Dean, J., Wilson, K., Ghassemi, E., \& Wilson, D. H. (2015). "But Many of These Problems are About Funds...": The Challenges Immigrant Settlement Agencies (ISAs) Encounter in a Suburban Setting in Ontario, Canada. Journal of International Migration and Integration, 17(2), 389-408.

Mwarigha, M. S. (2002). Towards a framework for local responsibility. Toronto, ON: Maytree Foundation. 
Ontario Council of Agencies Serving Immigrants (OCASI) (2011). Background Information on CIC Cuts. Retrieved from: http://www.ocasi.org/downloads/OCASI CIC Cuts Backgrounder.pdf

Ontario Council of Agencies Serving Immigrants (OCASI). (2012). Making ontario home 2012: A study of settlement and integration services for immigrants and refugees Ontario Council of Agencies Serving Immigrants.

Omidvar, R., Richmond, T., \& Laidlaw Foundation. (2003). Immigrant settlement and social inclusion in Canada Laidlaw Foundation.

Papillon, M. (2002). Immigration, diversity and social inclusion in Canada's cities. Canadian Policy Research Networks.

Richmond, T.,\& Shields, J.(2004). NGO restructuring: Constraints and consequences. Canadian Review of Social Policy, 53, 53-67.

Richmond, T., \& Shields, J. (2004). Third sector restructuring and the new contracting regime: The case of immigrant serving organizations in Ontario. Policy Matters, 3. Toronto, ON: CERIS.

Richmond, T., \& Shields, J. (2005). NGO-government relations and immigrant services: Contradictions and challenges. Journal of International Migration and Integration, 6(3), 513-526.

Sadiq, K. D., Doucet, M. J., Canada. Citizenship and Immigration Canada, \& CERIS. (2004). The two-tier settlement system: A review of current newcomer settlement services in Canada Joint Centre of Excellence for Research on Immigration and Settlement.

Saloojee, A. (2003). Social Inclusion, Anti Racism and Democratic Citizenship. Laidlaw Foundation: Perspectives on Social Inclusion, Working Paper Series. Retrieved http: laidlawfdn.org/library/laidlaw-publications/working- paper-series-on-social-inclusion/

Shields, J., Drolet, J., \& Valenzuela, K. (2016). Immigrant Settlement and Integration Services and the Role of Nonprofit Service Providers: A Cross-national Perspective on Trends, Issues and Evidence.

Shields J, Evans B and Richmond T (2005) Structuring neoliberal governance: The nonprofit sector, emerging new modes of control and the marketization of service delivery. Policy and Society 24(1): 73-97.

Shields, J., Turegun, A., Lowe, S. (2013). Final Report: Settlement and Integration Research Synthesis 2009 - 2013. Toronto, ON: CERIS.

Siemiatycki, M. \& Triadfilopoulos, T. (2010). International perspectives on immigrant service provision. Mowat Centre for Policy Innovation. Toronto, ON: University of Toronto. 
Simich, L., Beiser, M., Stewart, M., \& Mwakarimba, E. (2005). Providing social support for immigrants and refugees in Canada: Challenges and directions. Journal of Immigrant and Minority Health, 7(4), 259-268.

Solas, J. (2008). What kind of social justice does social work seek? International Social Work, 51(6), 813-822. doi:10.1177/0020872808095252

Statistics Canada. (2009). Meeting Immigrants' Expectations. Retrieved from: http:/ www41.statcan.gc.ca/2008/30000/ceb30000 001-eng.htm

Statistics Canada. (2011). Ethnic diversity and immigration. Retrieved from: http:/ www.statcan.gc.ca/pub/11-402-x/2011000/pdf/ethnic-ethnique-eng.pdf

Stasiulis, D., Hughes, C., \& Amery, Z. (2011). From Government to Multilevel Governance of Immigrant Settlement in Ontario's City-Regions. In Immigrant Settlement Policies in Canadian Municipalities, (p.73-148). McGill-Queen's University Press.

Tam, M. W. (2003). National Settlement Service and Standards Framework. Discussion paper developed for National Settlement Conference II, Calgary-October 2-5, 2003 (commissioned by National VSI Working Group IV on Settlement Standards, Professionalization, and Accountability). Retrieved December 1, 2012 (http://www. integration-net. ca/english/ini/vsi-isb/conference2/pdf/p04. pdf).

Tossutti, L. S. (2012). Municipal roles in immigrant settlement, integration and cultural diversity. Canadian journal of political science, 45(03), 607-633. Chicago

Tolley, E. \& Young, R., (2011). Immigrant settlement policy in Canadian municipalities McGillQueen's University Press.

Wilkinson, L. (2013). Introduction: developing and testing a generalizable model of immigrant integration. Canadian Ethnic Studies, 45(3), 1-7.

Young, R. (2011). Conclusion. In Immigrant Settlement Policies in Canadian Municipalities, (p. 295-321). McGill-Queen's University Press. 